International Journal of Agriculture, Environment and Bioresearch

Vol. 4, No. 05; 2019

ISSN: $2456-8643$

\title{
HEALTHY AND FUNCTIONAL INGREDIENTS FROM FRUIT PROCESSING BY- PRODUCTS: A REVIEW FOCUSING ON FRUIT PEELS
}

\author{
Zahid, H. F., Ranadheera, C. S., Fang, Z. and Ajlouni", S. \\ Affiliations: School of Agriculture \& Food, Faculty of Veterinary \& Agricultural Sciences, The University of \\ Melbourne, Melbourne VIC 3010, Australia \\ http://doi.org/10.35410/IJAEB.2019.4451
}

\begin{abstract}
Fresh and processed fruits represent a large segment in the nutritional and functional food sector and are highly popular among the health-conscious consumers. And the food processing operations are striving to meet that increasing demand for nutritious food products. Consequently, the fast-growing fruit processing businesses across the world have been generating great quantities of waste by-products including peels, pomace, husk, pods, stems and seeds which are usually discarded as waste. Although such fruit waste by-products are rich in nutrients and some functional ingredients, the inappropriate utilization and disposal is creating huge environmental problems. Hence, effective utilization of these by-products is essential. At present small amounts of certain fruit wastes are used as fertilizer or animal feed. However, a better economical and scientific approach to benefit from such waste by-products is to use them as sources of functional and nutritional ingredients. Moreover, the notion of resource optimization from the processing wastes could be a practical step towards achieving sustainable food production systems. This review focuses on the various scientific aspects and potential approaches for the utilization of fruit processing waste by-products, with special reference to fruit peels, in the food and nutraceutical applications.
\end{abstract}

Keywords: Agro-food waste, processing by-products, bioactive compounds, fruit peels.

\section{INTRODUCTION}

Domestic and international markets have seen a massive rise in the production, processing and merchandising of fruits due to the mounting acknowledgement of their therapeutic and nutritional potential (Ayala-Zavala et al., 2011). However, such continuous and significant increase in fruit production has been accompanied by rapid generation of huge amounts of waste by-products. For example, tropical fruits like mango, banana, papaya and pineapples are cherished solely for the fleshy tissues (mesocarp), whereas, the skin, seeds and pomes are removed during processing, thus contributing to large amounts of food wastes (Vega-Vega et al., 2013). The traditional disposal of these biodegradable wastes requires high biochemical oxygen demand, and badly affects the ecological, social and economic values. From an environmental perspective, these fruit residues are rich in moisture content together with higher levels of decomposable organic components which make them prone to microbial spoilage, resulting in an unacceptable stink during biodegradation (Wang et al., 2014). Therefore, the continuing removal of these wastes to the atmosphere not only marks the emission of greenhouse gases (GHG), but it also provides a breeding platform for pathogenic bacteria and various pests including mice and 
flies which causes the spread of disease and instigating problems to the society. Additionally, the costs of drying, storage, and shipment of such waste by-products are economically limiting aspects (Dhillon et al., 2013). Moreover, the economic effects can be viewed in terms of costs associated with food wastage, as the amount of the obtained wastes can even surpass the corresponding value produce. To overcome the costs involved and to improve the economics of food processing, further scientific handling of such by-products should be a viable alternative. The productive handling could be employed to isolate and extract some functional and health enhancing ingredients from these waste by-products for utilization by the food and nutraceutical industries (Sun-Waterhouse et al., 2009; Gorinstein et al., 2011).

Therefore, the call for possible recycling of agri-food by-products via novel technologies is continuously increasing (Yusuf, 2017). The common conventional strategies for waste management and minimization include landfilling, incineration, composting and fertilization and in animal feeding. However, the new waste management systems and treatments have attracted greater interest, that are focusing on reutilization and recovery of functional and nutritional constituents such as pectin, polyphenols, carotenoids, flavonoids and fibres (Arvanitoyannis,2008). Therefore, considering the global statutory requirements for waste removal, the European Union introduced a directive named as "Community Strategy for Waste Management". This concept emphasized a waste hierarchy of reuse, recycle and energy recovery for the prevention and mitigation of food residual waste (Directive, 1999). Since, food wastes in general are produced in various compositions and forms based on their seasonal and regional characteristics, the prospects of recovering sub-products for feed and food requirements differs largely from process to process. For example, the residues coming from fruits are phytochemicals, dietary fibres, food supplements and enzymes which are more likely to be exploited in the manufacture of innovative foodstuffs and for value-addition (Roselló-Soto et al., 2015). On the contrary, the potential wastes of the dairy sector include active proteins, peptides, lactose and fatty substances. Whereas, the resources contributed by meat industry constitute a considerable proportion of functional hydrolysates (Galanakis and Schieber, 2014; Otles et al., 2015). Consequently, a holistic recovery approach was presented by (Galanakis, 2012) which is called as "Universal Recovery Strategy". This concept involves the identification of waste compositions from a certain source followed by the collection of information regarding its availability, quantity and distribution. Afterwards, the characterization of collected samples at various levels is developed in a coherent manner. These identification and characterization processes allow the recapturing of beneficial compounds from the food waste and pave way towards the expansion of new and innovative products with increased market rate (Rahman et al., 2014). Nevertheless, a better understanding of successful utilization of agri-food waste is essential and latest information in these fields should be effectively disseminated both for scientific and non-scientific communities. Generally, agri-food wastes are rich in nutrients and extra nutritional complexes that are contributing to the gut health, weight management, reducing the blood cholesterol levels and refining the regulation of glycaemic and insulin responses (Bajerska et al., 2016). Some other exciting compounds which can be obtained from herbal wastes are mono-, di- and oligosaccharides, besides nondigestible oligosaccharide. These types of carbohydrates are currently considered as prebiotics. The nondigestible oligosaccharides can reach the colon undigested and undergo fermentation mainly by lactic acid bacteria, thus producing a healthy positive effect for the host (Diaz-Vela et al., 2013). Fruit peels are the major 
wastes by-products belong to the canned fruit and fruit juice processing industries. It is estimated that $20-40 \%$ weight of the total fruit is denoted by the peels of fruit (Wanlapa et al., 2015). Hence, there is a huge potential for utilization of fruit peels in recovering valuable and health promoting compounds. This review aims to, (1) describe the major agro-food waste by-products and their possible recycling strategies, (3) overview most significant bioactive compounds in fruit processing wastes, and (3) review the applications of fruit processing waste by-products in food and pharmaceutical industries. As most previous reviews have focused on fruit processing by-products in general, in this review, a special emphasis was given to fruit peels.

\section{AGRO-FOOD INDUSTRIAL WASTE AND THEIR ENVIRONMENTAL IMPLICATIONS}

Food waste is of a significant concern in the manufacturing industries worldwide. Mirabella et al. (2014) stated that food manufacturing industries in the developed countries are producing 39\% of food waste and it is becoming an issue in the developing countries as well. The food waste byproducts are generated throughout the food supply chain: initiating from the agriculture phase, up to manufacturing and processing, retailing and household. It has been reported that specific and accurate statistics on food waste quantity are difficult to find or to collect (Monier et al., 2010). However, the best presented estimates constitute a total food loss of around $89 \mathrm{Mt}$, or $179 \mathrm{~kg}$ per capita, in 2006. Food wastes can be produced along numerous phases of food supply chain, such as up to $42 \%$ losses occur in households, $39 \%$ of food waste is produced by the food manufacturing industry, $14 \%$ relates to food sector (ready to eat food and restaurants), and 5\% is misplaced along the supply chain. The same authors predicted that the amounts of food waste will grow to approximately $126 \mathrm{Mt}$ by 2020 if additional prevention strategies and policies are not commenced (Mirabella et al., 2014). Since ancient times, bio-waste products (e.g., peels, fruits, seeds, slurry, manure etc.) had been added to the soil as fertilizers. Such traditional methods of waste disposal are a universal concern to call for the development of alternate cleaning techniques that can utilize such wastes as renewable bioenergy reservoirs (Okonko et al., 2009). This traditional disposal of food processing waste involves a disbursement of millions of dollars (Okino et al., 2015). For example, the disposal cost of 1 ton of compact waste in Europe is $\$ 28-60$, including a landfill levy of $\$ 10$. Even though, landfill is a typical dumping technique, still it is the less efficient means to cope with the inevitable problem of environmental issue. It is also linked with the increased levels of greenhouse gas (GHG) emissions (Roggeveen, 2014). For example, GHG emissions associated with food processing by-products were suggested as third main promoters of environmental pollution behind the total emissions from USA and China (FAO, 2013). The GHG emissions related to food waste in Australia amounts to a total of $57,507 \mathrm{Gg}-\mathrm{CO} 2$ per year, which is about $6 \%$ of the total GHG emissions (Reutter et al., 2017). Many current literature reports suggested the use of pyrolysis assembly, which is specifically engineered to allow biomass heating at nominated temperatures, resulting in a product named as Biochar. In contrast to composting and landfilling, Biochar can cause a significant reduction in GHG emanations and can provide potential benefits to soil in terms of nutrient support (Aziz et al.,2015; Azni et al., 2019). Another more efficient way of waste byproducts management and recycling is altering these wastes into a favourable source of functional components that could be used because of their promising nutritional and functional attributes. The major target compounds $\mathrm{n}$ fruit wastes and by-products are listed in Table 1 . They 
Vol. 4, No. 05; 2019

ISSN: $2456-8643$

include proteins, polysaccharides, fats, fibres, phytochemicals, flavour compounds, and other bioactive compounds which can benefit the human health and the food industry (Helkar et al., 2016).

\section{DEMAND FOR HEALTHY FOODS}

In contemporary times, the alterations in life standards has shifted the focus of health-conscious society towards diet and its associated diseases. Key priority is to prevent the complications, particularly some chronic diseases arising from the poor diet which could be prevented following better lifestyle (Goetzke et al., 2014). Besides, exercising the practice of physical movement, enough nutrition is a vital aspect prompting one's health and wellbeing. Consumers' awareness about well-being and general quality of life has boosted the call for natural produces claimed to have nutritional and health benefits. This has provoked the industry and academia towards dietary guidelines as sources of vitamins, particularly vitamins A and C, minerals, and more lately health enhancing phytochemicals (Slavin and Lloyd, 2012). While the importance of fruits and vegetables being sources of nutrients and non-nutritive food ingredients is largely acknowledged, there are still doubts about their significance in the prevention of diseases. Boeing et al. (2012) comprehensively analysed the available literature and evaluated the results of respective studies regarding the effect of diet on various diseases. They concluded that a high daily consumption of fruits and vegetables promote health by preventing the risk of several chronic diseases including obesity, hypertension, type 2 diabetes mellitus, cancer, coronary heart disease (CHD), stroke, chronic inflammatory bowel disease (IBD), asthma, osteoporosis, eye diseases, and dementia. Many clinical studies support the role of the plant phytochemicals as health-promoting food components. For example, Bondonno et al. (2018) investigated the cardio protective effects of apples. Their findings suggested that apple with skin contains high flavonoid contents in comparison to apple flesh only. Moreover, a lower risk of cardiovascular disease was perceived with higher consumption of unpeeled apple and that effect was attributed to apple flavonoids.

\section{MAJOR FRUIT PROCESSING WASTE BY-PRODUCTS}

Fruits are the most popular natural food items by the reason of their nutritional worth and rich of valuable anti-oxidants, vitamins, minerals and fibres (Rahman et al., 2014). Examples of the substantial amounts of fruits generated worldwide include 124.73 megatons (Mt) of citrus, 74.49Mt of grapes, 84.63 Mt of apples, 114.08 Mt of bananas, 25.43 Mt of pineapples, and 45.22 Mt of mangoes, mangosteens, and guavas (FAO, 2017). The industrial manufacturing of these fruits generates approximately $50 \%$ of the original weight as waste by-product in various forms such as pomace, peels, cores, unripe and/ or damaged fruits (Padayachee et al., 2017). Such industrial waste by-products are less likely to be deteriorated as compared to the household food waste. Therefore, sensible use of these by-products can assist in the alleviation of nutritional problems, generation of revenue for the industry and yielding beneficial health effects (TorresLeón et al.,2018). Many recent works have been focused on these aspects of waste by-products nutritional, revenue and health benefits utilization (Table 2). Noor et al. (2014) reported that fruit processing waste by-products could be used not only as a good source of bioactive compounds but also as value-added ingredients to some food products. Recently, fruit processing by- 
products from certain fruits including banana, mango and apple have attracted great attention of the scientific community as a result of their significant potential in recovering health and functional components.

\subsection{Mango}

Mango (Mangifera indica L.) is majorly cultivated in tropical and subtropical parts around the world. Asia is the leading producer of mango (75.6\%), followed by America (13.4\%) and finally Africa (11\%) (FAOSTAT, 2017). An appreciable volume of by-products, such as peels (13-16\%) and seeds (9.5-25\%), are generated as a result of mango fruit processing (Torres-León et al.,2017). The same authors indicated that mango seed has a very good profile of carbohydrates (58-8-\%), essential amino acids with proteins (6-13\%), and lipids (6-16\%). The physicochemical characteristics associated with mango seed lipids resembles those of cocoa butter (Jahurul et al.,2015). Whereas, mango peel (MP) is a key element of mango processing which accounts for $15-20 \%$ of total weight of mango fruit. Mango peel contains total dietary fibre (TDF) in the ranges of $28 \%$ to $78 \%$, where the soluble dietary fibre represents $13 \%-28 \%$ and insoluble dietary fibre content is $14-50 \%$. Such increased level of dietary fibres in MP places it in the list of important food additives for functional food formulations (Ajila et al., 2008).

\subsection{Banana}

Mostly, banana (Musa acuminate) is consumed in tropical and subtropical areas of the world. its contribution to the global food import market is $13.1 \%$ with a generation of US\$14,595.1 million per annum (SEICA, 2016). The major by-product comes from banana processing business is the peel, that constitutes approximately 30-40\% of the fruit (Babbar et al., 2011). As the fruits of banana are eaten at green and ripe stages, the massive accumulation of these wastes urges the need for the formulation of appropriate strategies for recycling and utilization of these residues. The possible applications of banana peels are determined by the chemical composition of their chemical compounds (Pelissari et al., 2013). Banana peel (BP) comprises high content of dietary fibre principally insoluble dietary fibre (11.04\%) and saturated fatty acids which constitutes $40-50 \%$ of the fatty acids. In addition, BP is rich in phytochemicals with potential antioxidant properties, essential amino acids and vitamins (Venkateshwaran and Elayaperumal, 2010; Pelissari et al., 2013). The extraction and utilization of these compounds from food wastes contributes to the reduction of environmental pollution and the development of functional and value-added food ingredients (Venkateshwaran and Elayaperumal, 2010).

\subsection{Apple}

Apple (Malus domestica) is the 4th most commonly cultivated fruit globally (Konarska, 2013). Apple fruit flesh as well as pulp, seeds and peel possess therapeutic properties (Thilakarathna et al., 2013). Studies revealed that apple peel contains more phenolic compounds than the flesh (Bondonno et al., 2018). Moreover, it has high antioxidant and antiproliferative activity (Kalinowska et al., 2014). These phenolic compounds in apple peels play an imperative part as a shield for the indigenous material from insects and pathogenic and spoilage microorganisms. They contribute to the colour and appearance of the fruits as well. Similar to what has been 
discussed under mango and banana peels, the proper recycling of apple peel can yield excellent functional and healthy phenolic compounds.

\section{BIOACTIVE COMPOUNDS IN FRUIT WASTE BY-PRODUCTS}

Fruit wastes are excellent reserves of phytochemicals and are studied for the possible extraction of polyphenols, fibres, and other bioactive ingredients (Galanakis, 2012). Effective utilization and recovery of these components leads towards the notion of zero waste. This concept (zero waste) is an efficient approach which allows the valorisation of agro waste materials to valuable products and the detection of newer components with precise roles in human metabolism (Saini et al.,2019). The major bioactive compounds that can be obtained from fruits processing wastes and their characteristics health benefits are discussed in the following sections.

\subsection{Phenolic compounds and their health benefits}

Phenolics are the phytochemicals which are known to be the principal bioactive compounds in fruits for their health benefits. Phenolic compounds have attracted an appreciable amount of attention because of the public awareness about the direct association between ingested food with high phytochemical content and health (Varzakas et al., 2016). The incorporation of these compounds in diet is a resourceful tool to deter the adverse effects instigated by reactive oxygen species (ROS) in human body. This oxidative pressure, triggered by the ROS, is measured as one of the core causes of some serious illnesses, including cancer, diabetes, cardiovascular and neurodegenerative diseases (Socaci et al., 2017). Fruit peel wastes could be excellent reservoirs of bioactive phenolic compounds that can be utilized to protect against such diseases. Apples are known for their high contents of phenolic compounds with excellent health benefits. There are four most prominent polyphenolic groups in apples such as, flavanols, flavan-3-ols, phenolic acids and dihydrochalcones (Ceymann et al., 2012). The in vitro testing of apple polyphenols showed significant development of glutathione S-transferases, reduction in the generation of $\mathrm{H} 2 \mathrm{O} 2$, inhibition against oxidative-induced DNA damage and obstruction of intestinal glucose absorption (Schulze et al., 2014). McCann et al. (2007) revealed the potential of phenolic extracts from apple waste (by-products of juice extraction) to affect numerous colon cancer biomarkers, i.e. colonocyte barrier function, DNA damage and cell cycle progression. Studies on apple peel revealed the scope of this waste in ameliorating and antagonizing the lethal complications of diabetes mellitus (Fathy and Drees, 2015) and acute liver damage (Nie et al.,2015). Similarly, mango peel contains many bioactive compounds, such as phenolics, vitamins, carotenoids and terpenoids. Moreover, syringic, gallic, protocatechuic and ferulic acids are phenolic acids recognized in the bound phenolic segment of mango peel dietary fibre. Among the identified bound flavonoids were kaempferol, quercetin and rutin (Ajila and Rao, 2013). Formerly, it has been found that phenolics from mango peels exhibit antagonistic effects against various degenerative diseases related to oxidative stress (Torres-León et al., 2017). Inhibition of adipogenesis and the anti-cancer properties are some of the health benefits associated with mango polyphenols (Pierson et al., 2015). Mangiferin is the highly documented phenolic compound from mango waste owing to its pharmacological traits such as antiviral and antiproliferative effects (Gold-Smith et al., 2016). It can significantly avert the development of cardiovascular problems that are corelated to nephritis and hyperlipidaemia in diabetes (Pal et 
al.,2014). Mangiferin has been reported as an efficient neuro protector in relation to its capability to reverse amnesia, probably because of its capacity to obstruct leukotrien and prostaglandins, which are produced by lipoxygenases and cyclooxygenases respectively (Bhatia et al., 2008). Apart from its medicinal properties, there are revelations about its chemotherapeutic and chemo preventive outcomes. Keeping in view the diverse therapeutic applications of mangiferin, both the peel and its extracts could find their use as a potential drug in future (Saha et al., 2016).

Likewise, observations and the identification of health promoting bioactive chemicals such as, dietary fibres, carbohydrates, certain vitamins have been reported in banana peel (Pelissari et al.,2013). The polyphenols and carotenoids from banana peel are considered as of prime importance because of their manifold benefits and certain medicinal attributes such as ant carcinogens and antimutagenic effects. The peel extracts from banana fruit have shown numerous protective effects against several ailments such as oxidation induced haemolysis (Sundaram et al., 2011), hepatic injury (Wang et al., 2016) liver dysfunction (Mosa and Khalil, 2015), and ulceration (Onasanwo et al., 2013). Moreover, some of the recent works on banana peels have find the usage of these by-products in aquaculture, as a feed additive and as a safeguard to certain infections (Rattanavichai and Cheng, 2014; Giri et al., 2016).

\subsection{Dietary fibres and their health benefits}

Typically, fibres in wheat, rice and corn have been widely used in food processing and in nutraceuticals both for the purpose of their health characteristics and technological functions (Liand Komarek, 2017). Since many years, dietary fibre (DF) has received positive consideration due to its therapeutic properties (Anderson et al., 2009). It has also been used as a food ingredient with specific functions, such as gelling ability, water binding and structure building and as a fat replacer in some food systems (Telrandhe et al., 2012). It is a broad group of indigestible food constituents that includes oligosaccharides, non-starch polysaccharides, alike polysaccharides and lignin with allied health benefits (Raninen et al., 2011). In general, DF is categorized based on its solubility in water, viscosity and bacterial fermentation in the gut. Soluble DFs include polysaccharides, pectin and gums, while insoluble DFs include cellulose, hemicellulose and lignin (Dai and Chau, 2017). The chemical assembly of DF is the determinant of its biological functions. Soluble dietary fibre undertakes microbial degradation in the gastrointestinal tract and influence carbohydrates and fat metabolism, whereas insoluble dietary fibres curtail the gastrointestinal transit time, thus improve gut health. Dietary fibre sourced from fruits shows a higher quality as compared to other sources because of its increased total and soluble fibre contents, good hydration capacities, excellent colonic fermentability, poor phytic acid values and lower caloric contents. Wanlapa et al. (2015) evaluated the chemical composition, functional aspects and virulence of dietary fibres obtained from the skins of seven tropical fruits. All fruit peels presented high content of total dietary fibre $(52-84 \mathrm{~g} / 100 \mathrm{~g}$ dry matter) and showed significant differences in the quality of dietary fibre. The authors suggested that peels of tropical fruits exposed abundant potential to be employed as lowcalorie but useful ingredients for the enrichment of dietary fibre. For example, mango peel powder when incorporated into some cereal based products such as, macroni preparation, it exhibited a rise in the total dietary fibre and antioxidant properties of the product. Ajila et al. (2010) suggested that mango peel powder could augment the nutritional and nutraceutical properties of macronies. 
Apple peel is a waste product from apple juice industry. The phenolic compounds, dietary fibre, and mineral contents in apple peel are higher than in other edible parts of apple fruits (Henríquez et al., 2010). A study by Leontowicz et al. (2003) examined the dietary fibre content of a whole apple, its peel and its pulp. Interestingly, they found that most of the total fibre was in the peel $(0.91 \%$ fresh weight $)$. Further, the proportion of insoluble $(0.46 \% \mathrm{FW})$ to soluble fibre $(0.43 \%$ FW) was found to be well maintained in the sense of receiving a health benefit. Analysis of mango peel dietary fibre revealed higher percent in the range of $40.6 \%$ to $72.5 \%$, where the major sugars in both soluble and insoluble fibres were glucose, galactose and arabinose (Ajila and Rao, 2013). Orange peel has also been known as an excellent source of fibre in addition to antioxidants, sugars, essential oils and a few minerals. Chau and Huang (2003) reported that orange peel contained 57\% dry weight (DW) total dietary fibre $(47.6 \%$ insoluble and $9.41 \%$ soluble). Pectic polysaccharides and cellulose were determined as the major constituents of orange peel fibre. The fruit waste by-products, being rich sources of dietary fibres and bioactive elements could be an additional source of income for food processors if utilized properly. Customers expect a natural supplement, free from cytotoxic and synthetic ingredients, which can be sourced from the fruit waste by-products. DF possess several advantageous nutritious and protective effects (Li \& Komarek, 2017). The literature from the past two decades has documented several health benefits of DF. Numerous diseases such as obesity, cardiovascular diseases, colon cancer and diabetes could be prevented as a result of beneficial effects of DF. It has been demonstrated that enough intake of DF has lowered the risk of developing stroke, type2 diabetes and cardiovascular diseases (Ye et al., 2012; Threapleton et al., 2013; Ning et al., 2014). Additionally, adequate intake of fibre is recommended to aid in weight management, mainly through satiety or fullness regulation ( $\mathrm{Li}$ et al., 2014), and seems to expand immune functions in terms of gut health and fibre-microbiota interactions (Dong et al., 2016). Moreover, the occurrence of civilization-induced diseases has been associated to the inappropriate intake of DF by some epidemiological findings (Nawirska and Kwaśniewska, 2005).

\section{PREBIOTIC EFFECTS OF FRUIT PEELS}

It is well documented that fruit peels possess appreciable biological activities due to their prebiotic effects in comparison with other fractions of fruits (Ashoush and Gadallah, 2011). Prebiotic is defined as a non-digestible compound that, through its metabolization by microorganisms in the gut, modulates composition and/or activity of the gut microbiota, thus conferring a beneficial physiologic effect on the host (Bindels et al., 2015). Prebiotic dietary fibres are specific, microbiota-shaping compounds that function as a carbon source for the growth of beneficial bacteria, thus delivering a specific change that confers the host health related to its metabolism (Carlson et al., 2018). Over the past 15 years, heaps of information have been collected on prebiotics to understand their active mechanisms and to explicate their advantageous health effects on humans (Anandharaj et al., 2014). Several studies suggested the utilization of fruit peels as prebiotics. Akhtar et al. (2015) explored the potential of pomegranate peel and peel extracts as food preservatives, prebiotics and as food quality enhancers. Similarly, pineapple peel powder and cactus pear peels were assessed as alternate carbon sources throughout bacterial fermentation (Diaz-Vela et al., 2013). Kinetic parameters indicated that both pear and pineapple peel flours were equally suitable carbon sources as they allowed the lactic acid bacteria to grow and to acidify the culture media due to their prebiotic potential. Sayago- 
Ayerdi et al. (2019) examined the prebiotic properties of pre-digested mango peel in an authenticated in vitro model. The production of beneficial branched chain fatty acids (BCFA), short chain fatty acids (SCFA)and ammonia profiles were detected in both lumen and dialysates. Manuel (2014) studied the effect of pectin derived from discarded fruits on the growth of health promoting probiotic microorganisms. The results suggested that extracted pectin enhanced the number of Lactobacillus acidophilus and Bifidobacterium bifidum, and the presence of pectin with prebiotic properties supported the endurance of the probiotics in the digestive tract at exciting acidic to alkaline conditions. In another study by Gómez et al. (2014) pectic oligosaccharides (POS) from orange peel wastes were assessed for their prebiotic potential by in vitro colonic fermentation using human faecal inoculum. Microbial populations were assessed by fluorescent in sit hybridization (FISH). Additionally, gas generation, $\mathrm{pH}$, and SCFA production were also measured. Results showed an increase in the number of lactic acid bacteria population, particularly the numbers of bifid bacteria and lactobacilli. The amount of generated SCFA were similar to those observed using fructo-oligosaccharides (FOS). Prebiotic ingredients from fruit peel and by-products clearly have a significant positive effect not only on both probiotic growth and survival in food products but also gut microbiota upon consumption.

The colon is the most highly colonized and metabolically active region of the human GI tract, with up to $1012 \mathrm{cfu} / \mathrm{g}$ of gut microbiota (Gibson et al., 2010). The major functions of gut microbiota include, prevention of colonization of potentially pathogenic microorganisms, fermentation of non-digestible carbohydrates to organic acids, and modulation of the immune system. The major nutrient substrates reach the colon for fermentation are non-digestible carbohydrates, (including resistant starch, cellulose, pectin, inulin and oligosaccharides) and residual proteins (Scott et al.,2013). Human alimentary enzymes are unable to degrade complex carbohydrates, these are digested by microbes which generate short-chain fatty acids (SCFAs), such as butyrate, acetate and propionate, which are beneficial to host health (Holscher, 2017). Therefore, inclusion of prebiotics in diet is important for establishing a healthy gut microbiota, and fruit processing by-products including peels with prebiotic potential could contribute to host health.

\section{APPLICATION OF FRUIT PEEL DERIVED PRODUCTS IN THE FOOD INDUSTRY}

It has been well documented that fruit wastes can be a vital source of micronutrients, vitamins and other phytochemicals that can be utilized in food fortification (Varzakas et al., 2016). These valuable constituents can be extracted by appropriate physical and chemical treatments (Wang and Lai, 2016). Access to these techniques offers a prospect to the finest usage of these explicit components. A study of the literature revealed that the most underlying extraction technologies are mainly solvent extraction (SE), enzymatic hydrolysis, supercritical fluid extraction (SFE), microwave and ultrasound assisted extraction (Kumar et al., 2017). Therefore, biotechnological advancement has led the way towards comprehensive utilization of these constituents in the food and pharmaceutical industries. For example, Göksel Saraç and Dogan (2016) examined the effect of adding dietary fibre concentrates (DFC), sourced from various fruits and vegetable wastes, on bio-functional and sensory aspects of butter. They concluded that incorporation of food waste derived ingredients to butter improved its textural and sensory parameters. As a processing byproduct, various fruit peels may contain a variety of active compounds that can turn such wastes 
into functional ingredients. Thus, introducing peel flours in food formulations could offer viable options for the exploitation of waste both on monetary and practical grounds. Coelho et al. (2017) studied the technological properties of passion fruit peel flours and compared them with five commercial additives. They concluded that the skin of passion fruit is good source of fibre with properties similar to some food additives. The passion fruit peel flour samples were evaluated for their thickening, stabilizing and gelling ability. The flour samples exhibited rich attributes, in ice cream toppings, as thickening and gelling agent. The same results demonstrated

that the commercial hydrocolloids can be replaced by the flour produced from passion fruit peel. In another study by Al-Sahlany and Al-musafer (2018) wheat flour in bread dough was substituted with banana peel flour (BPF). They concluded that BPF could be beneficial for improving the rheological properties and yeast numbers in bead dough. A summary of various recent applications of fruit peel derived products and ingredients in the food systems are presented in Table 3.

\section{APPLICATION OF FRUIT PEEL POWDER IN THE PHARMACEUTICAL INDUSTRY}

In addition to the significant importance of fruit peels in the food industries, they do also contain important chemical composition and good pharmacological properties (Hassan, 2016). Fruits wastes are rich sources of phytochemicals which can be used for prevention and treatment of various diseases including obesity, type 2-diabetes, cardiovascular disease, cancer and respiratory problems. For example, a study by Tow et al. (2011) examined the total polyphenolic contents of industrial apple waste including apple peel for their ant proliferation effects on human cancer cells. Their results revealed that non-extractable polyphenols (NEPPs) from industrial apple waste could be a good source of antioxidants with significant ant proliferation against human cancer cells.

The pharmaceuticals extracted from some fruits waste by-products can help improving human health, delaying the aging process, preventing chronic diseases, increasing life expectancy, and support the structure or function of the human body (Nasri et al., 2014). Additionally, the medically important ingredients obtained from plant source, in general, are considered excellent because they have fewer or no undesirable side effects (Joshi et al., 2012). However, the application of fruit processing by-products including peels remained mostly less investigated and poorly utilized.

\section{CONCLUDING REMARKS}

Many scientific patents have addressed the nutritional effects of various bioactive components, especially those related to fruits and vegetables compounds. However, the recent trends among the scientific community and food sector are focusing on the exploration of new and affordable ingredient with health benefits and added values. In this regard, the fruit waste by-products represent a likely solution both in terms of availability and possessing significantly higher levels of multi-functional bio components. Extensive research has shown that fruit processing waste by-products are rich in dietary fibres and important phytochemicals that can contribute to the 
human health. However, procurement of purified dynamic compounds is somewhat challenging for the food industry as well as for the consumers, since it requires some scaled-up procedures.

Implementation of appropriate management tools and scientific extraction principles could result in a better recycling of fruits waste by-products and improve the social, economic and environmental profits.

\section{REFERENCES:}

Ajila, C. M., Aalami, M., Leelavathi, K. and Rao, U. J. S. P. 2010. Mango peel powder: A potential source of antioxidant and dietary fibre in macaroni preparations. Innovative Food Science\& Emerging Technologies 11(1): 219-224. doi: 10.1016/j.ifset.2009.10.004

Ajila, C. M., Leelavathi, K. and Rao, U. 2008. Improvement of dietary fiber content and antioxidant properties in soft dough biscuits with the incorporation of mango peel powder. Journal of Cereal Science 48(2): 319-326. doi: 10.1016/j.jcs.2007.10.001

Ajila, C. M. and Rao, U. 2013. Mango peel dietary fibre: Composition and associated boundphenolics. Journal of Functional Foods 5(1): 444-450. doi: 10.1016/j.jff.2012.11.017

Akhtar, S., Ismail, T., Fraternale, D. and Sestili, P. 2015. Pomegranate peel and peel extracts: Chemistry and food features. Food Chemistry 174: 417-425.

Al-Sahlany, S. T. G. and Al-musafer, A. M. S. 2018. Effect of substitution percentage of banana peels flour in chemical composition, rheological characteristics of wheat flour and the viability of yeast during dough time. Journal of the Saudi Society of Agricultural Sciences.

Anandharaj, M., Sivasankari, B. and Parveen Rani, R. 2014. Effects of probiotics, prebiotics, and symbiotic on hypercholesterolemia: a review. Chinese Journal of Biology.

Anastopoulos, I. and Kyzas, G. Z. 2014. Agricultural peels for dye adsorption: A review of recent literature. Journal of Molecular liquids 200: 381-389.

Anderson, J. W., Baird, P., Davis, R. H., Ferreri, S., Knudtson, M., Koraym, A., Waters, V. and Williams, C. L. 2009. Health benefits of dietary fibre. Nutrition reviews 67(4): 188-205.

Arvanitoyannis, I. S. 2008. Waste management in food packaging industries. International Series, 941 .

Ashoush, I. and Gadallah, M. 2011. Utilization of mango peels and seed kernels powders as sources of phytochemicals in biscuit. World Journal of Dairy Food Science 6(1): 35-42.

Avhad, R., Sarode, N., Khair, N. and Dhadage, K. 2017. Utilization of mango pee powder (MPP)in mango nectar formulation. International Journal of Current Microbiology and Applied Sciences 6(4): 14-19.

Ayala-Zavala, J. F., Vega-Vega, V., Rosas-Domínguez, C., Palafox-Carlos, H., Villa-Rodriguez, J. A., Siddiqui, M. W., Dávila-Aviña, J. E. and González-Aguilar, G. A. 2011. Agro- 
industrial potential of exotic fruit by-products as a source of food additives. Food Research International 44(7): 1866-1874. doi: 10.1016/j.foodres.2011.02.021

Aziz, N. S. b. A., Nor, M. A. b. M., Manaf, S. F. B. A. and Hamzah, F. 2015. Suitability of Biochar Produced from Biomass Waste as Soil Amendment. Procedia - Social and Behavioural Sciences 195: 2457-2465. doi: 10.1016/j.sbspro.2015.06.288

Azni, A. A., Ghani, W. A. W. A. K., Idris, A., Ja'afar, M. F. Z., Salleh, M. A. M. and Ishak, N. S.2019. Microwave-assisted pyrolysis of EFB-derived biochar as potential renewable solid fuel for power generation: Biochar versus sub-bituminous coal. Renewable Energy 142: 123-129. doi: $10.1016 /$ j.renene.2019.04.035

Babbar, N., Oberoi, H. S., Uppal, D. S. and Patil, R. T. 2011. Total phenolic content and antioxidant capacity of extracts obtained from six important fruit residues. Food Research International 44(1): 391-396. doi: 10.1016/j.foodres.2010.10.001

Bajerska, J., Mildner-Szkudlarz, S., Górnaś, P. and Seglina, D. 2016. The effects of muffins enriched with sour cherry pomace on acceptability, glycaemic response, satiety and energy intake: a randomized crossover trial. Journal of the Science of Food and Agriculture 96(7):24862493.

Bhatia, H. S., Candelario-Jalil, E., de Oliveira, A. C. P., Olajide, O. A., Martínez-Sánchez, G. and Fiebich, B. L. 2008. Mangiferin inhibits cyclooxygenase-2 expression and prostaglandin E2 production in activated rat microglial cells. Archives of Biochemistry and Biophysics 477(2): 253-258.

Bindels, L. B., Delzenne, N. M., Cani, P. D. and Walter, J. 2015. Towards a more comprehensive concept for prebiotics. Nature reviews Gastroenterology \& hepatology 12(5): 303.

Boeing, H., Bechthold, A., Bub, A., Ellinger, S., Haller, D., Kroke, A., Leschik-Bonnet, E., Muller,

M. J., Oberritter, H., Schulze, M., Stehle, P. and watzl, B. 2012. Critical review: vegetables and fruit in the prevention of chronic diseases. European journal of nutrition 51(6): 637- 663.

Bondonno, N. P., Bondonno, C. P., Blekkenhorst, L. C., Considine, M. J., Maghzal, G., Stocker, R., Woodman, R. J., ward, N. C., Hodgson, J. M. and Croft, K. D. 2018. Flavonoid-Rich

Apple Improves Endothelial Function in Individuals at Risk for Cardiovascular Disease: A Randomized Controlled Clinical Trial. Molecular Nutrition \& Food Research 62(3). doi:10.1002/mnfr.201700674

Carlson, J. L., Erickson, J. M., Lloyd, B. B. and Slavin, J. L. 2018. Health effects and sources of prebiotic dietary fibre. Current developments in nutrition 2(3): nzy005. 
Cervantes-Martínez, C., Medina-Torres, L., González-Laredo, R., Calderas, F., SánchezOlivares, G., Herrera-Valencia, E., Gallegos Infante, J. A., Rocha-Guzman, N. E. and RodriguezRamirez, J. 2014. Study of spray drying of the Aloe Vera mucilage (Aloe vera barbadensis Miller) as a function of its rheological properties. LWT-Food Science and Technology 55(2): 426-435.

Ceymann, M., Arrigoni, E., Schärer, H., Nising, A. B. and Hurrell, R. F. 2012. Identification of apples rich in health-promoting flavan-3-ols and phenolic acids by measuring the polyphenol profile. Journal of Food Composition and Analysis 26(1-2): 128-135.

Chau, C. F. and Huang, Y. L. 2003. Comparison of the Chemical Composition and Physicochemical Properties of Different Fibres Prepared from the Peel of Citrus sinensis L. Cv. Liucheng. Journal of Agricultural and Food Chemistry 51(9): 2615-2618.

Chen, Y., Zhao, L., He, T., Ou, Z., Hu, Z. and Wang, K. 2019. Effects of mango peel powder on starch digestion and quality characteristics of bread. International Journal of Biological Macromolecules 140: 647-652.

Coelho, E. M., Gomes, R. G., Machado, B. A. S., Oliveira, R. S., dos Santos Lima, M., d Azêvedo, L. C. and Guez, M. A. U. 2017. Passion fruit peel flour-Technological properties and application in food products. Food hydrocolloids 62: 158-164.

Dai, F. J. and Chau, C. F. 2017. Classification and regulatory perspectives of dietary fibre. Journal of food and drug analysis 25(1): 37-42.

Deng, G. F., Shen, C., Xu, X. R., Kuang, R. D., Guo, Y. J., Zeng, L. S., Gao, L. L., Lin, X., Xie, J. F., Xia, E. Q., Li, S., Wu, S., Chen, F., Ling, W. H. and Li, H. B. 2012. Potential of fruit wastes as natural resources of bioactive compounds. International journal of molecular sciences 13(7): 8308-8323.

Dhillon, G. S., Kaur, S. and Brar, S. K. 2013. Perspective of apple processing wastes as low-cost substrates for bioproduction of high value products: A review. Renewable and sustainable energy reviews 27: 789-805.

Diaz-Vela, J., Totosaus, A., Cruz-Guerrero, A. E., \& de Lourdes Pérez-Chabela, M. (2013). In vitro evaluation of the fermentation of added-value agroindustrial by-products: cactus pear $(\mathrm{O}$ puntia ficus-indica L.) peel and pineapple (A nanas comosus) peel as functional ingredients. International Journal of Food Science \& Technology, 48(7), 1460-1467.

Directive, C. (1999). 99/31/EC on the Landfill of Waste. OJ L, 182, 26.

Dong, H., Sargent, L. J., Chatzidiakou, Y., Saunders, C., Harkness, L., Bordenave, N., Rowland, I., Spencer, J. P. E. and Lovegrove, J. A. 2016. Orange pomace fibre increases a composite scoring of subjective ratings of hunger and fullness in healthy adults. Appetite 107: 478-485. 
Dorta, E., González, M., Lobo, M. G., Sánchez-Moreno, C. and de Ancos, B. 2014. Screening of phenolic compounds in by-product extracts from mangoes (Mangifera indica L.) by HPLC- ESIQTOF-MS and multivariate analysis for use as a food ingredient. Food Research International 57: 51-60. doi: 10.1016/j.foodres.2014.01.012

IFAD, W. 2013. FAO (2013). The State of Food Insecurity in the World: The multiple dimensions of food security.

FAO. 2017. FAO Statistics Data 2014. Available from: www.fao.org/faostat/en/łdata. Accessed 2017 June 26.

FAOSTAT (2017). FAO Statistics, Food and Agriculture Organization of the United Nations. FAOSTAT.

Fathima, S. and Puraikalan, Y. D. 2013. Development of Food Products using pomegranate skin. International Journal of Science and Research 4(3).

Fathy, S. M. and Drees, E. A. 2015. Protective effects of Egyptian cloudy apple juice and apple peel extract on lipid peroxidation, antioxidant enzymes and inflammatory status in diabetic rat pancreas. BMC complementary and alternative medicine 16(1): 8. Faustino, M., Veiga, M., Sousa, P., Costa, E. M., Silva, S. and Pintado, M. 2019. Agro-Food

By-products as a New Source of Natural Food Additives. Molecules 24(6). doi: 10.3390/molecules24061056

Ferrentino, G., Asaduzzaman, M. and Scampicchio, M. M. 2018. Current technologies and new insights for the recovery of high valuable compounds from fruits by-products. Critical Reviews in Food Science and Nutrition 58(3): 386-404. doi:10.1080/10408398.2016.1180589

Fiorentino, Fiorentino, A., Dabrosca, B., Pacifico, S., Mastellone, C., Scognamiglio, M. and Monaco, P. 2009. Identification and Assessment of Antioxidant Capacity of Phytochemicals from Kiwi Fruits. Journal of Agricultural and Food Chemistry 57(10): 41484155 .

Galanakis, C. M. 2012. Recovery of high added-value components from food wastes: conventional, emerging technologies and commercialized applications. Trends in Food Science \& Technology 26(2): 68-87.

Galanakis, C. M. and Schieber, A. 2014. Recovery and utilization of valuable compounds from food processing by-products. Food Research International 65: 299-484.

Gibson, G. R., Scott, K. P., Rastall, R. A., Tuohy, K. M., Hotchkiss, A., Dubert-Ferrandon, A., Gareau, M., Murphy, E. F., Saulnier, D., Loh, G., Macfarlane, S., Delzenne, N., Ringel, Y., Kozianowski, G., Dickman, R., Lenoir-Wijnkoop, I., Walker, C. and Buddington, R. 2010. Dietary prebiotics: current status and new definition. Food Science \& Technology Bulletin Functional Foods 617 7(1): 1-19. 
Giri, S. S., Jun, J. W., Sukumaran, V. and Park, S. C. 2016. Dietary administration of banana (Musa acuminata) peel flour affects the growth, antioxidant status, cytokine responses, and disease susceptibility of rohu, Labeo rohita. Journal of immunology research. Goetzke, B., Nitzko, S. and Spiller, A. 2014. Consumption of organic and functional food. A matte of wellbeing and health? Appetite 77: 96-105.

Göksel Saraç, M. and Dogan, M. 2016. Incorporation of dietary fibre concentrates from fruit and vegetable wastes in butter: effects on physicochemical, textural, and sensory properties. European Food Research and Technology 242(8): 1331-1342. doi:10.1007/s00217-016- 2637-9

Gold-Smith, F., Fernandez, A. and Bishop, K. 2016. Mangiferin and cancer: Mechanisms of action. Nutrients 8(7): 396.

Gómez, B. n., Gullón, B., Remoroza, C., Schols, H. A., Parajó, J. C. and Alonso, J. L. 2014. Purification, characterization, and prebiotic properties of pectic oligosaccharides from orange peel wastes. Journal of Agricultural and Food Chemistry 62(40): 9769-9782.

Gorinstein, S., Poovarodom, S., Leontowicz, H., Leontowicz, M., Namiesnik, J., Vearasilp, S., Haruenkit, R., Ruamsuke, P., Katrich, E. and Tashma, Z. 2011. Antioxidant properties and bioactive constituents of some rare exotic Thai fruits and comparison with conventional fruits: in vitro and in vivo studies. Food Research International 44(7): 2222-2232.

Hassan, F. 2016. Pharmacological evaluation of fruit peel. International Journal of Pharmaceutical Science and Research 1(1): 37-39.

Helkar, P. B., Sahoo, A. and Patil, N. 2016. Review: Food industry by-products used as a functional food ingredient. International Journal of Waste Resources 6(3): 1-6.

Henríquez, Henríquez, C., Speisky, H., Chiffelle, I., Valenzuela, T., Araya, M., Simpson, R. and Almonacid, S. 2010. Development of an Ingredient Containing Apple Peel, as a Source of Polyphenols and Dietary Fiber. Journal of Food Science 75(6): H172-H181.

Holscher, H. D. 2017. Dietary fiber and prebiotics and the gastrointestinal microbiota. Gut microbes 8(2): 172-184.

Huber, G. M. and Rupasinghe, H. P. 2009. Phenolic profiles and antioxidant properties of apple skin extracts. Journal of Food Science 74(9): C693-700. doi:10.1111/j.1750-3841.

Jahurul, M. H., Zaidul, I. S., Ghafoor, K., Al-Juhaimi, F. Y., Nyam, K. L., Norulaini, N. A., Sahena, F. and Mohd Omar, A. K. 2015. Mango (Mangifera indica L.) by-products and their valuable components: a review. Food Chemistry 183: 173-180. doi: 10.1016/j.foodchem.2015.03.046

Jahurul, M. H. A., Zaidul, I. S. M., Beh, L., Sharifudin, M. S., Siddiquee, S., Hasmadi, M., Sahena, F., Mansoor, A. H., Lee, J. S. and Jinap, S. 2019. Valuable components of bambangan fruit (Mangifera pajang) and its co-products: A review. Food Research International 115: 105 115. doi: 10.1016/j.foodres.2018.08.017 
Joshi, V., Kumar, A. and Kumar, V. 2012. Antimicrobial, antioxidant and phyto-chemicals from fruit and vegetable wastes: A review. International Journal of Food and Fermentation Technology 2(2): 123.

Jun, Y., Bae, I. Y., Lee, S. and Lee, H. G. 2013. Utilisation of preharvest dropped apple peels as a flour substitute for a lower glycaemic index and high fiber cake. International Journal of Food Sciences and Nutrition 65(1): 62-68.

Kalinowska, M., Bielawska, A., Lewandowska-Siwkiewicz, H., Priebe, W. and Lewandowski, W. (2014). Apples: content of phenolic compounds vs. variety, part of apple and cultivation model, extraction of phenolic compounds, biological properties. Plant Physiology and Biochemistry 84: 169-188. doi: 10.1016/j.plaphy.2014.09.006

Konarska, A. 2013. The structure of the fruit peel in two varieties of Malus domestica Borkh. (Rosacea) before and after storage. Protoplasma 250(3): 701-714. doi:10.1007/s00709- 0120454-y

Kumar, K., Yadav, A. N., Kumar, V., Vyas, P. and Dhaliwal, H. S. 2017. Food waste: a potential bioresource for extraction of nutraceuticals and bioactive compounds. Bioresources and Bioprocessing 4(18). doi:10.1186/s40643-017-0148-6

Leontowicz, Leontowicz, M., Gorinstein, S., Leontowicz, H., Krzeminski, R., Lojek, A., Katrich, E., Ciz, M., Martin-Belloso, O., Soliva-Fortuny, R., Haruenkit, R. and Trakhtenberg, S. 2003. Apple and Pear Peel and Pulp and Their Influence on Plasma Lipids and Antioxidant Potentials in Rats Fed Cholesterol-Containing Diets. Journal of Agricultural and Food Chemistry 51(19): 5780-5785.

Li, S. S., Kendall, C. W., de Souza, R. J., Jayalath, V. H., Cozma, A. I., Ha, V., Mirrahimi, A., Chiavaroli, L., Augustin, L. S., Blanco Mejia, S., Leiter, L. A., Beyene, J., Jenkins, D. J. and Sievenpiper, J. L. 2014. Dietary pulses, satiety and food intake: A systematic review and metaanalysis of acute feeding trials. Obesity 22(8): 1773-1780.

Li, Y. O. and Komarek, A. R. 2017. Dietary fibre basics: Health, nutrition, analysis, and applications. Food Quality and Safety 1(1): 47-59. doi:10.1093/fqsafe/fyx007

Liew, Liew, S., Chin, N. and Yusof, Y. A. 2014. Extraction and Characterization of Pectin from Passion Fruit Peels. Agriculture and Agricultural Science Procedia 2: 231-236.

Majerska, J., Michalska, A. and Figiel, A. 2019. A review of new directions in managing fruit and vegetable processing by-products. Trends in Food Science \& Technology 88: 207-219. doi: 10.1016/j.tifs.2019.03.021

Manuel, S. G. A. 2014. Fruit Waste Pectin in Enhancing the Establishment of Probiotic Bacteria. Journal of Nutritional Health \& Food Engineering 1(3). doi:10.15406/jnhfe.2014.01.00018 
Martinez-Giron, J., Figueroa-Molano, A. M. and Ordonez-Santos, L. E. 2017. Effect of the addition of peach palm (Bactris gasipaes) peel flour on the colour and sensory properties of cakes. Food science and Technology 37(3).

McCann, M., Gill, C., O’Brien, G., Rao, J., McRoberts, W., Hughes, P., McEntee, R. and Rowland, I. R. 2007. Anti-cancer properties of phenolics from apple waste on colon carcinogenesis in vitro. Food and Chemical Toxicology 45(7): 1224-1230.

Mirabella, N., Castellani, V. and Sala, S. 2014. Current options for the valorisation of food manufacturing waste: a review. Journal of Cleaner Production 65: 28-41.

Monier, V., Mudgal, S., Escalon, V., O'Connor, C., Gibon, T., Anderson, G. and Montoux, H. 2010. Preparatory Study on Food Waste Across EU 27: Technical Report. European Commission.

Mosa, Z. M. and Khalil, A. F. 2015. The effect of banana peels supplemented diet on acute liver failure rats. Annals of Agricultural Sciences 60(2): 373-379.

Nasri, H., Baradaran, A., Shirzad, H. and Rafieian-Kopaei, M. 2014. New concepts in nutraceuticals as alternative for pharmaceuticals. International Journal of Preventive Medicine 5(12): 1487.

Nawirska, A. and Kwaśniewska, M. 2005. Dietary fibre fractions from fruit and vegetable processing waste. Food Chemistry 91(2): 221-225.

Nguyen, T. A. H., Ngo, H. H., Guo, W. S., Zhang, J., Liang, S., Yue, Q. Y., Li, Q. and Nguyen, T. V. 2013. Applicability of agricultural wastes and by-products for adsorptive removal of heavy metals from wastewater. Bioresource Technology 148: 574-585.

Nie, Y., Ren, D., Lu, X., Sun, Y. and Yang, X. 2015. Differential protective effects of polyphenol extract from apple peels and fleshes against acute $\mathrm{CCl} 4$-induced liver damage in mice. Food and function 6(2): 513-524.

Ning, H., Van Horn, L., Shay, C. M. and Lloyd-Jones, D. M. 2014. Associations of dietary fibre intake with long-term predicted cardiovascular disease risk and C-reactive protein levels (from the National Health and Nutrition Examination Survey Data [2005-2010]). The American Journal of Cardiology 113(2): 287-291.

Noor, F., Rahman, M. J., Mahomud, M. S., Akter, M. S., Talukder, M. A. I. and Ahmed, M. 2014. Physicochemical properties of flour and extraction of starch from jackfruit seed. International Journal of Nutrition and Food Sciences 3(4): 347-354.

Okino Delgado, C. H., \& Fleuri, L. F. (2015). Orange and mango by-products: Agro-industrial waste as source of bioactive compounds and botanical versus commercial description-A review. Food Reviews International, 32(1), 1-14. doi:10.1080/87559129.2015.1041183 
Okonko, I. O., Adeola, O., Aloysius, F., Damilola, A. and Adewale, O. 2009. Utilization of food wastes for sustainable development. Electronic Journal of Environmental, Agricultural and Food Chemistry 8(4): 263-286.

Onasanwo, S., Emikpe, B., Ajah, A. and Elufioye, T. 2013. Anti-ulcer and ulcer healing potentials of Musa sapientum peel extract in the laboratory rodents. Pharmacognosy Research 5(3): 173-178.

Otles, S., Despoudi, S., Bucatariu, C. and Kartal, C. 2015. Food waste management, valorisation, and sustainability in the food industry. Food Waste Recovery 3-23.

Padayachee, A., Day, L., Howell, K. and Gidley, M. 2017. Complexity and health functionality of plant cell wall fibres from fruits and vegetables. Critical reviews in food science and nutrition 57(1): 59-81.

Pal, P. B., Sinha, K. and Sil, P. C. 2014. Mangiferin attenuates diabetic nephropathy by inhibiting oxidative stress mediated signalling cascade, $\mathrm{TNF} \alpha$ related and mitochondrial dependent apoptotic pathways in streptozotocin-induced diabetic rats. PloS one 9(9): e107220.

Patel, S. 2012. Potential of fruits and vegetable wastes as novel bio sorbents: summarizing the recent studies. Reviews in Environmental Science and Bio/Technology 11(4): 365-380.

Pelissari, F. M., Sobral, P. J. d. A. and Menegalli, F. C. 2013. Isolation and characterization of cellulose nanofibers from banana peels. Cellulose 21(1): 417-432. doi:10.1007/s10570- 0130138-6

Pierson, J.-T., Curry, M. C., Shaw, P. N., Dietzgen, R. G., Gidley, M. J., Roberts-Thomson, S. J. and Monteith, G. R. 2015. Polyphenolic contents and the effects of methanol extracts from mango varieties on breast cancer cells. Food Science and Biotechnology 24(1): 265-271.

Radočaj, O., Vujasinović, V., Dimić, E. and Basić, Z. 2014. Blackberry (Rubus fruticosus L.) and raspberry (Rubus idaeus L.) seed oils extracted from dried press pomace after longterm frozen storage of berries can be used as functional food ingredients. European Journal of Lipid Science and Technology 116(8): 1015-1024.

Rafiq, S., Kaul, R., Sofi, S. A., Bashir, N., Nazir, F. and Ahmad Nayik, G. 2018. Citrus peel as a source of functional ingredient: A review. Journal of the Saudi Society of Agricultural Sciences 17(4): 351-358. doi: 10.1016/j.jssas.2016.07.006

Rahman, J., Talukder, A., Hossain, F., Mahomud, S., Islam, M. A. and Shamsuzzoha, M. 2014. Detection of Cryptosporidium oocytes in commonly consumed fresh salad vegetables. American Journal of Microbiological Research 2(6): 224-226.

Rana, S., Gupta, S., Rana, A. and Bhushan, S. 2015. Functional properties, phenolic constituents and antioxidant potential of industrial apple pomace for utilization as active food ingredient. Food Science and Human Wellness 4(4): 180-187. doi: 10.1016/j.fshw.2015.10.001 
Raninen, K., Lappi, J., Mykkänen, H. and Poutanen, K. (2011). Dietary fibre type reflects physiological functionality: comparison of grain fibre, inulin, and polydextrose. Nutrition reviews 69(1): 9-21.

Rattanavichai, W. and Cheng, W. 2014. Effects of hot-water extract of banana (Musa acuminata) fruit's peel on the antibacterial activity, and anti-hypothermal stress, immune responses and disease resistance of the giant freshwater prawn, Macrobrachium rosenbegii. Fish \& shellfish immunology 39(2): 326-335.

Reutter, B., Lant, P., Reynolds, C. and Lane, J. 2017. Food waste consequences: Environmentally extended input-output as a framework for analysis. Journal of Cleaner Production 153: 506-514.

Roggeveen, K. 2014. Tomato journeys from farm to fruit shop. Local Environment 19(1): 77102.

Roselló-Soto, E., Barba, F. J., Parniakov, O., Galanakis, C. M., Lebovka, N., Grimi, N. and Vorobiev, E. 2015. High voltage electrical discharges, pulsed electric field, and ultrasound assisted extraction of protein and phenolic compounds from olive kernel. Food and Bioprocess Technology 8(4): 885-894.

Rotta, E. M., de Morais, D. R., Biondo, P. B. F., dos Santos, V. J., Matsushita, M. and Visentainer, J. V. 2016. Use of avocado peel (Persea americana) in tea formulation: a functional product containing phenolic compounds with antioxidant activity. Acta Scientarium Technology 38(1): 23-29.

Sagar, N. A., Pareek, S., Sharma, S., Yahia, E. M. and Lobo, M. G. 2018. Fruit and Vegetable Waste: Bioactive Compounds, Their Extraction, and Possible Utilization. Comprehensive Reviews in Food Science and Food Safety 17(3): 512-531. doi:10.1111/1541-4337.12330

Saha, S., Sadhukhan, P. and Sil, P. 2016. Mangiferin: A xanthonoid with multipotent antiinflammatory potential. BioFactors 42(5): 459-474.

Saini, A., Panesar, P. S. and Bera, M. B. 2019. Valorisation of fruits and vegetables waste through green extraction of bioactive compounds and their Nano emulsions-based delivery system. Bioresources and Bioprocessing 6(1). doi:10.1186/s40643-019-0261-9

Sayago-Ayerdi, S. G., Zamora-Gasga, V. M. and Venema, K. 2019. Prebiotic effect of predigested mango peel on gut microbiota assessed in a dynamic in vitro model of the human colon (TIM-2). Food Research International 118: 89-95. doi: 10.1016/j.foodres.2017.12.024

Schulze, C., Bangert, A., Kottra, G., Geillinger, K. E., Schwanck, B., Vollert, H., Wolfgang, B. and Daniel, H. 2014. Inhibition of the intestinal sodium-coupled glucose transporter 1 (SGLT1) by extracts and polyphenols from apple reduces postprandial blood glucose levels in mice and humans. Molecular Nutrition \& Food Research 58(9): 1795-1808. 
Scott, K. P., Gratz, S. W., Sheridan, P. O., Flint, H. J. and Duncan, S. H. (2013). The influence of diet on the gut microbiota. Pharmacological Research 69(1): 52-60.

Shan, Shan, B., Cai, Y.-Z., Brooks, J. and Corke, H. 2011. Potential Application of Spice and Herb Extracts as Natural Preservatives in Cheese. Journal of Medicinal Food 14(3): 284-290.

SIECA (2016). Análisis de La Competitividad Regional Del Mercado de Frutas. Secretaría de Integración Económica Centroamericana.

Sicari, V., Pellicano, T. M., Lagna, V. and Poiana, M. 2017. Use of orange by-products (dry peel) as an alternative gelling agent for marmalade production: Evaluation of antioxidant activity and inhibition of HMF formation during different storage temperature. Journal of Food Processing and Preservation 42(2): e13429.

Slavin, J. L. and Lloyd, B. 2012. Health benefits of fruits and vegetables. Advances in Nutrition 3(4): 506-516.

Socaci, S. A., Rugină, D. O., Diaconeasa, Z. M., Pop, O. L., Fărcaș, A. C., Păucean, A., Tofana, M. and Pintea, A. 2017. Antioxidant Compounds Recovered from Food Wastes. In Functional Food - Improve Health through Adequate Food.

Sun-Waterhouse, D., Wen, I., Wibisono, R., Melton, L. D. and Wadhwa, S. 2009. Evaluation of the extraction efficiency for polyphenol extracts from by-products of green kiwifruit juicing. International Journal of Food Science \& Technology 44(12): 2644-2652.

Sundaram, S., Anjum, S., Dwivedi, P. and Rai, G. K. 2011. Antioxidant activity and protective effect of banana peel against oxidative haemolysis of human erythrocyte at different stages of ripening. Applied Biochemistry and Biotechnology 164(7): 1192-1206.

Telrandhe, U. B., Kurmi, R., Uplanchiwar, V., Mansoori, M., Raj, V. and Jain, K. 2012. Nutraceuticals-A phenomenal resource in modern medicine. International Journal of Universal Pharmacy and Life Sciences 2(2): 179-195.

Thilakarathna, S. H., Rupasinghe, H. V. and Needs, P. W. 2013. Apple peel bioactive rich extracts effectively inhibit in vitro human LDL cholesterol oxidation. Food Chemistry 138(1): 463-470.

Threapleton, D. E., Greenwood, D. C., Evans, C. E., Cleghorn, C. L., Nykjaer, C., Woodhead, C., Cade, J. E., Gale, C. P. and Burley, V. J. 2013. Dietary fibre intake and risk of cardiovascular disease: systematic review and meta-analysis. Bmj 347. doi: https://doi.org/10.1136/bmj.f6879

Torres-León, C., Ramírez-Guzman, N., Londoño-Hernandez, L., Martinez-Medina, G. A., DíazHerrera, R., Navarro-Macias, V., Alvarez-Pérez, O. B., Picazo, B., Villarreal-Vázquez, M., Ascacio-Valdes, J. and Aguilar, C. N. 2018. Food Waste and By-products: An Opportunity to Minimize Malnutrition and Hunger in Developing Countries. Frontiers in Sustainable Food Systems 2(52). doi:10.3389/fsufs.2018.00052 
Torres-León, C., Rojas, R., Serna-Cock, L., Belmares-Cerda, R. and Aguilar, C. N. 2017. Extraction of antioxidants from mango seed kernel: Optimization assisted by microwave. Food and Bioproducts Processing 105: 188-196. doi: 10.1016/j.fbp.2017.07.005

Tow, W. W., Premier, R., Jing, H. and Ajlouni, S. 2011. Antioxidant and antiproliferation effects of extractable and non-extractable polyphenols isolated from apple waste using different extraction methods. Journal of Food Science 76(7): T163-172. doi:10.1111/j.1750-3841.2011. 02314.x

Umesh Hebbar, H., Sumana, B. and Raghavarao, K. S. 2008. Use of reverse micellar systems for the extraction and purification of bromelain from pineapple wastes. Bioresource Technology 99(11): 4896-4902. doi: 10.1016/j.biortech.2007.09.038

Varzakas, T., Zakynthinos, G. and Verpoort, F. 2016. Plant food residues as a source of nutraceuticals and functional foods. Foods 5(4): 88.

Vega-Vega, V., Silva-Espinoza, B. A., Cruz-Valenzuela, M. R., Bernal-Mercado, A. T., González- Aguilar, G. A., Vargas-Arispuro, I., Corrales-Maldonado, C. G. and Ayala-Zavala, J. F. 2013. Antioxidant enrichment and antimicrobial protection of fresh-cut mango applying bioactive extracts from their seeds by-products. Food and Nutrition Sciences 4(08): 197.

Venkateshwaran, N. and Elayaperumal, A. 2010. Banana Fibre Reinforced Polymer CompositesA Review. Journal of Reinforced Plastics and Composites 29(15): 2387-2396. doi: $10.1177 / 0731684409360578$

Wang, C. and Lai, Q. 2016. Advances in comprehensive utilization of fruit peel in China. Academia Journal of Agricultural Research 4(9): 589-592.

Wang, L., Shen, F., Yuan, H., Zou, D., Liu, Y., Zhu, B. and Li, X. 2014. Anaerobic co-digestion of kitchen waste and fruit/vegetable waste: Lab-scale and pilot-scale studies. Waste Management 34(12): 2627-2633.

Wang, R., Feng, X., Zhu, K., Zhao, X. and Suo, H. 2016. Preventive activity of banana peel polyphenols on CCl4-induced experimental hepatic injury in Kunming mice. Experimental and therapeutic medicine 11(5): 1947-1954.

Wanlapa, S., Wachirasiri, K., Sithisam-ang, D. and Suwannatup, T. 2015. Potential of selected tropical fruit peels as dietary fibre in functional foods. International Journal of Food Properties 18(6): 1306-1316.

Ye, E. Q., Chacko, S. A., Chou, E. L., Kugizaki, M. and Liu, S. 2012. Greater whole-grain intake is associated with lower risk of type 2 diabetes, cardiovascular disease, and weight gain. The Journal of Nutrition 142(7): 1304-1313.

Younis, K., Islam, R. U., Jahan, K., Yousaf, B. and Ray, A. 2015. Effect of addition of mosambi (Citrus limetta) peel powder on textural and sensory properties of papaya jam. Cogent Food and Agriculture 1(1). 
International Journal of Agriculture, Environment and Bioresearch

Vol. 4, No. 05; 2019

ISSN: $2456-8643$

Yusuf, M. 2017. Agro-industrial waste materials and their recycled value-added applications. Handbook of Eco materials 1-11. 
Table 1. Functional ingredients recovered from fruit waste by-products

\begin{tabular}{|c|c|c|c|}
\hline Fruits & By-product & Functional ingredient & Reference \\
\hline Pomegranate & Peel & Ellagitannins & (Akhtar et al., 2015) \\
\hline \multirow[t]{2}{*}{ Mango } & Seed & Ellagic acid & (Dorta et al., 2014) \\
\hline & Peel & $\begin{array}{l}\text { Quercetin, 1,2,3,4,6-penta-O- } \\
\text { galloryl- } \beta \text { - D- glucose }\end{array}$ & \\
\hline Citrus & Peel & $\begin{array}{l}\text { Dietary fiber and phenolic } \\
\text { compounds }\end{array}$ & (Rafiq et al., 2018) \\
\hline \multirow[t]{2}{*}{ Apple } & Pomace & $\begin{array}{l}\text { Total dietary fiber and phloridzin, } \\
\text { quercetin, phloretin }\end{array}$ & (Rana et al., 2015) \\
\hline & Skin & $\begin{array}{l}\text { Proanthocyanidins, flavan-3-ols, } \\
\text { flavonols and anthocynins }\end{array}$ & $\begin{array}{l}\text { (Huber and } \\
\text { Rupasinghe, 2009) }\end{array}$ \\
\hline Pineapple & $\begin{array}{l}\text { Peel, core, } \\
\text { crown, stem }\end{array}$ & Proteolytic enzyme - bromelain & (Umesh et al., 2008) \\
\hline Blueberry & Peel & $\begin{array}{l}\text { gallic acid, Epicatechin, catechin, } \\
\text { cyanidin 3-glucoside and } \\
\text { Chlorogenic acid }\end{array}$ & (Deng et al., 2012) \\
\hline Avocado & Stone & $\begin{array}{l}\text { Cyanidin 3-glucoside, catechin, } \\
\text { homogentisic acid, and chlorogenic acid }\end{array}$ & (Deng et al., 2012) \\
\hline $\begin{array}{l}\text { Blackberry, } \\
\text { Raspberry }\end{array}$ & $\begin{array}{l}\text { Seed and } \\
\text { pomace }\end{array}$ & $\begin{array}{l}\text { Linoleic acid (omega-6) and } \alpha \text { - } \\
\text { linoleic acid (omega-3) }\end{array}$ & (Radočaj et al., 2014) \\
\hline Pineapple & Peel & Dietary fibers & \\
\hline Kiwi fruit & Peel & Vitamin E, $\alpha$ - and $\delta$ - tocopherol & $\begin{array}{l}\text { (Fiorentino et al., } \\
\text { 2009) }\end{array}$ \\
\hline Passion fruit & Peel & Pectin & (Liew et al., 2014) \\
\hline Grape & Seeds & $\begin{array}{l}\text { Phenolic compounds and } \\
\text { Flavonoids }\end{array}$ & (Shan et al., 2011) \\
\hline
\end{tabular}




\section{International Journal of Agriculture, Environment and Bioresearch}

Vol. 4, No. 05; 2019

ISSN: $2456-8643$

Table 2. Recently published reviews on fruit wastes: Food and non-food applications

\begin{tabular}{|c|c|}
\hline Contents & References \\
\hline $\begin{array}{l}\text { Overview of methods for determining antioxidant activity and extraction } \\
\text { of polyphenolic compounds from fruit residue }\end{array}$ & (Babbar et al., 2011) \\
\hline $\begin{array}{l}\text { Innovative and green extraction technologies for the extraction of } \\
\text { biocomponents and enhancement of extraction yield }\end{array}$ & (Ferrentino et al., 2018) \\
\hline $\begin{array}{l}\text { The nutritional and functional properties of pomegranate peel and their } \\
\text { application as food additives }\end{array}$ & (Akhtar et al., 2015) \\
\hline $\begin{array}{l}\text { Recovery and recycling of agro industrial waste and their application as } \\
\text { nutraceutical and functional components }\end{array}$ & (Mirabella et al., 2014) \\
\hline $\begin{array}{l}\text { Exploration of the nutraceutical assets of bambangan fruit (Mangifera } \\
\text { pajang) and its by-products based on their health improving } \\
\text { phytochemicals }\end{array}$ & (Jahurul et al., 2019) \\
\hline Highlights on the valorization approach of different agricultural peels & $\begin{array}{l}\text { (Anastopoulos and Kyzas, } \\
2014 \text { ) }\end{array}$ \\
\hline $\begin{array}{l}\text { Potential use of agricultural wastes as biosorbents for removal of heavy } \\
\text { metals from wastewater }\end{array}$ & (Nguyen et al., 2013) \\
\hline $\begin{array}{l}\text { Incorporation of food waste byproducts in various foodstuffs as } \\
\text { multifunctional food additives with antioxidant and antimicrobial } \\
\text { properties }\end{array}$ & (Faustino et al., 2019) \\
\hline $\begin{array}{l}\text { Recovery of medicinal components from food waste and the prevention of } \\
\text { chronic and protracted diseases }\end{array}$ & (Kumar et al., 2017) \\
\hline $\begin{array}{l}\text { An updated summary of alternative adsorbents developed from fruits and } \\
\text { vegetables wastes for carcinogenic pollutants removal from waste water }\end{array}$ & (Patel, 2012) \\
\hline $\begin{array}{l}\text { Extraction and purification of antioxidants from food wastes and their } \\
\text { underlying potential regarding health benefits }\end{array}$ & (Socaci et al., 2017) \\
\hline $\begin{array}{l}\text { Potential utilization of generated wastes of fruits and vegetables, their } \\
\text { extraction techniques and bioactive compounds }\end{array}$ & (Sagar et al., 2018) \\
\hline $\begin{array}{l}\text { Various dimensions of managing fruit and vegetable pomace in food } \\
\text { industry as enrichment materials }\end{array}$ & (Majerska et al., 2019) \\
\hline
\end{tabular}


Table 3. Recent applications of fruit peel derived products in the food systems

\begin{tabular}{|c|c|c|c|}
\hline Fruit peel type & Food Application & Highlights/ Contents & References \\
\hline Peach palm peel & Cake & $\begin{array}{l}\text { Increased total carotenoid } \\
\text { contents, natural food dye } \\
\text { alternative in bread } \\
\text { products }\end{array}$ & $\begin{array}{l}\text { (Martinez-Giron et al., } \\
\text { 2017) }\end{array}$ \\
\hline Orange peel & Marmalade & $\begin{array}{l}\text { Analytical parameters } \\
\text { (stability, antioxidant } \\
\text { effect) were maintained }\end{array}$ & (Sicari et al., 2017) \\
\hline Pomegranate peel & $\begin{array}{l}\text { Idli (popular savoury } \\
\text { rice cake type in } \\
\text { Indian subcontinent }\end{array}$ & $\begin{array}{l}\text { Highest score was } \\
\text { recorded for overall } \\
\text { acceptability in sensory } \\
\text { evaluation }\end{array}$ & $\begin{array}{l}\text { (Fathima and } \\
\text { Puraikalan, 2015) }\end{array}$ \\
\hline $\begin{array}{l}\text { Mosambi (Citrus } \\
\text { limetta) peel }\end{array}$ & Papaya jam & $\begin{array}{l}\text { Significant increase in } \\
\text { firmness and chewiness } \\
\text { values of jam }\end{array}$ & (Younis et al., 2015) \\
\hline Apple peel & High fiber cake & $\begin{array}{l}\text { Resistant starch levels } \\
\text { increased and lower } \\
\text { glycemic index }\end{array}$ & (Jun et al., 2013) \\
\hline Mango peel & Mango nectar & $\begin{array}{l}\text { Mango peel powder } \\
\text { beyond } 1 \mathrm{~g} \text { decreased the } \\
\text { overall acceptability }\end{array}$ & (Avhad et al., 2017) \\
\hline Avocado peel & Tea formulation & $\begin{array}{l}\text { Exhibited good } \\
\text { antioxidant activity and } \\
\text { good acceptability }\end{array}$ & (Rotta et al., 2016) \\
\hline Mango peel & Bread & $\begin{array}{l}\text { Peel powder induced } \\
\text { reduction in the rate of } \\
\text { starch digestion }\end{array}$ & (Chen et al., 2019) \\
\hline
\end{tabular}

